\title{
Assessing the Effects of 'Stand-alone' Structuration of Land Administration System on Urban Land Delivery and Accessibility in Nigeria
}

\author{
Akinbola Kazeem Bolayemi \\ The Federal Polytechnic llaro, Department of Estate Management \&Valuation, Nigeria
}

Md Yassin Azlina

Universiti Tun Hussein Onn Malaysia, Department of Real Estate \& Facilities Management, Malaysia

\begin{abstract}
The efficiency and effectiveness of land administration system had been acknowledged to be premised on so many factors, arguably the chief of which, is the degree of mutuality, frictionlessness and bidirectionality in the interrelationship that exist amongst the various factors that are discharging arrays of tasks that these formal lands regulo-administrative machineries are saddled with. Undoubtedly, this simple conduct of affairs resultantly drives the formal lands delivery, hence it increases accessibility to urban lands by several categories of users in Nigeria, as thus the case globally. However, these interrelationships are absent among land administration and regulation systems in Nigeria. Hence, this study intends to assess the direct and possible indirect impacts that these interrelationships fallouts have on the formal delivery and accessibility of urban lands in Nigeria, Firstly, this was done by articulating the issues involved and calibrating them into constructs, then measuring them via the following score-cards, thus: myopism, non-ingenuity, disservice, ecofinancial loss, distrust, trauma, anti-growth, death, market distortion and thriving informalisation focussing on the South Western Nigeria. Out of the total 586 individuals considered as the total population for the sample space, 120 individual qualified for the sample frame, upon which the structured questionnaires were distributed among land regulators, land administrators, independent land consultants and ultimate land users, essentially to have a fair and broad view of the issues inherent in this lands accessibility dilemma. 93 questionnaires were retrieved, out of which 87 questionnaires were valid, thus formed the basis upon which analyses were done, with emphasis on the 5 point Likert scale measurement usage, via both inferential and descriptive statistical tools. The results showed amongst other things, that unbridled relationship frictions had led to unwarranted role jettisoning and this impacts adversely on the delivery pace which concomitantly warps formal pathway to accessing urban lands by various categories of land users. Among the recommendations are that government formal land agencies should be re-configured to build synergy that engenders positive interrelationship and role synchronisation towards improved formal land delivery and accessibility in Nigeria.
\end{abstract}

Keywords: Impacts; Interrelationship; Regulo-Administrative Machineries; Formal Land Accessibility; Nigeria.

UDC 631.1

JEL Classification: Q15, Q24, R52

DOI: http://dx.doi.org/10.22178/pos.17-17

\section{Introduction}

This study is framed within the proposition that irrespective of how determined land administration and regulation systems in Nigeria are, to achieve the desirable level of globallycompetitive edge and to meet up with the required tempo of service delivery in advancing the course of developmental aspirations of Nigerians of the 21st century thinking, these land administration and regulation system must as a matter of urgency improve very tremendously on the type, latitude and complexion of the interrelationship that exists between them. Although, the formal land administration systems in Nigeria are continuously striving to improve upon their erstwhile appalling level of productivity, but the truth be told, that unless some drastic and decisive measures on straightening their lopsidedlyrivalled interrelationship are urgently taken, the LASs as they presently function are far lesser than what is acceptable to be attuned with the dictates of the global best practices, hence they 
greatly fall short of meeting with ever-increasing demands and complex-driven requirements of the teeming population of Nigerians who are yearning for land upon where to build $[13,11]$.

Therefore, it has become a recurring decimal within the purveying of Nigeria's land administration and regulation system, for the contributing units and divisions to get so rivalry in their interrelationship to the extent of damaging not only themselves as actors in the land delivery and accessibility debate, but even taking it beyond this level to that which is getting anarchical, the end results of which are highly counterproductive to the overall realisation of the very essence behind their creation in the first place. Sadly to note that, the variable(s) at the receiving end all these uninteresting scenario are the prospective land users, who desperately need the expertise and services of these government agencies, in respect of their land needs. However, it is evident that in the recent years, the vivid evidences of trends depicting the malfunctioning of the bureaucratically-enshrined formal land delivery system, the glaring implication of the reason for this abysmal performance of the public land delivery system has led to the unprecedented rearing and thriving of the informal land delivery arrangement, with its ugly manifestations of agony of various dimensions [21, 22].

Hence, from the foregoing it appears that the persistent poor performance of the formal land delivery system has created a conducive environment for the blossoming of informal land supply and development. The informal sector seems to have taken over the leading role in supplying of lands for housing development of various classes. Land as one of the major real estate development factors is essentially indispensable and its administration is thus crucial for hitchfree supply, with a view to making it easily accessible for adequate housing production. A Land Administration System (LAS) is the platform for implementing government policies and land management strategies. It is also a means to achieving development objectives and improving the wellbeing of the society, among other ranges of socio-economic goals [10].

However, it has become resoundingly clear that nothing so meaningfully developmental can be so achieved by our formal land administration and regulation system until this present sorry state of affairs as it borders on interrelationship imbroglio among all actors that are domiciled in vari- ous units and divisions of our formal LASs.is addressed, because it is through this, that formallycontrolled and regulated lands could be supplied, so as to possibly halt the presently consistent paving way for an increasingly-thriving informal land market arrangement, through buying, leasing, and even admixture of lease-develop-operate and transfer mechanisms, among others $[15,17]$. Hence, this research was conducted to assess and gauge the direct and possible indirect impacts that these interrelationships fallouts have on the formal delivery and accessibility of urban lands in Nigeria, by articulating the myriads of issues involved and then calibrating them into measurable constructs, against which the these interrelationship imbroglio could be best conceived, with a view to better appreciate the challenges thereof, so as to proffer practicable solution to them towards improving formal delivery and accessibility of urban lands, thus increasing the stock of real estate as well as engendering the possession of land and housing rights in Nigeria.

\section{Literature review and conceptual clarifications}

The prospective advantage of institutional economics cannot be over-emphasised in shaping the way and manner our land administration functions are arranged into departmentalised units and divisions, so as to give each of them unique identity that goes with the kind of functions they have been evolved to render. Often times, efforts are made particularly in the evolvement of a theoretical framework for land management and in an attempt to advance the present frontier of body of knowledge in institutional economics [2]. New institutional economics is an admixture of topical components culled from economics, law and political science [18, $20]$ and offers a platforms for the study of the institutional organisations as independent variables alongside their rights and responsibilities, as well as the nature of contributions they make in transactions cycles [19].

Therefore, Land administration is a basic institutional infrastructure for effective and efficient land management, as a more comprehensive understanding of the principles of institutional arrangements is further required for sound interrelationships among land policies, land administration systems and land management activities The importance of the roles played by organisational institutions such as land administration and 
regulation systems are better understudied and properly contextualised for possible improved performance through in-depth analyses that are incisive about the contribution that interrelationship among these several supposedly interrelated units and divisions should have to truly realise an all-round socio-political and economic development [24].

Institutional organisations are defined as a set of formal and informal rules of conduct(s) that facilitate the coordination of relationships between and /or among individuals and groups [28]. Institutions are also being recognised as a set of formal and informal rules which govern the roles of actors and control the interactions between and / or among them [12]. Zakout refers to governmental and nongovernmental social systems as institutions. Hence, land administration is being influenced by these same institutional and organisational aspects in many countries, has previous commentaries on institutional perspectives such as Molen and Enemark [20] have significantly affected the thinking of scholars in land administration and management studies.

Though most of the people are familiar with the term institution as being a simple 'rules of the game', but this term called institution is more complex, as an established framework of cooperation and interaction in relation to social aspects of society. The main role of institutions has been recognised to minimise the conditions of uncertainty by setting up a comprehensive arrangement [6], as the creation of wellorchestrated and robust structures can largely determine the attitudes of people and organisations through the rules and regulations implemented [10]. It is thus assumed whenever institutions are being defined, that the institutions function like the rules of a game in society, where the stakeholders involved are the organisations who act as players Abdullah [2]. Simply put, institutions must be larger horizons than organisations, though in terms of implementation, institutions may be affected by several main formal and informal constraints, such as law, regulation and property rights could be formal constraints, while culture, custom and incentives can be seen as informal constraints clogging effective land management [8].

Moreover, institutions are divided into three categories, these are: constitutional order, institutional arrangements, and normative behavioural practices. Institutional arrangement has been highlighted as the governance structure as, which is further deepened by the new institutional economics and it encompasses two phases: micro and macro levels [7]. The micro level deals with the context of institutional arrangements that includes laws, regulations, property rights, long-term contracts, public bureaucracies, nonprofit organisations and contractual agreements [3], while social, political, and legal aspects are considered to be macro level [6].

Therefore, it is noteworthy that the nature of the backgrounds of most countries in the areas of history, culture, economics and politics commonly influence the arrangement of land administration systems that are put in place [1]. However, the type of system involved, whether decentralised, deconcentrated or centralised determines the institutional arrangement of land administration in operation [12]. It was assumed that the formulation of land policy is dependent upon the category of land tenure, the nature of enforcement that is applicable to land market in administering private and public land as well as the method of land policy development. Hence, land administration arrangements have responsibility for land survey, land registration, land valuation, land control, land settlement and infrastructures and utilities, as the implementation of land administration as a whole is being influenced by each system's type: decentralised, deconcentrated or centralised [5].

The management of land offers platform(s) for the development of land policy, the evolvement of plans for use and development of land as well as the implementation of land administration [27]. Institutional perspectives and approaches in land management and land administration are useful and beneficial for structuring, analysing, planning and developing frameworks in the social sense [25], as it also encompasses both private and public sectors in the proper functioning of land policy, administration, and management activities [26].

However, as distinct from previous researchers, [16] contextualise and refer to land administration institutions as the rules of the game in accordance with accepted laws and regulations, as well as key organisations as key players that ensure the operation of the institutions involved, as institutional arrangements need effective organisation to enhance their capability in society. However, the legal and institutional conflicts arising from several land administration studies 
have been identified and divided into three main issues which capture these real conflicts and challenges, these are the failure of institutions as it relates to basic arrangements, a lack of policy implementation, or a disregard for revision for the purpose of enhancing existing processes and procedures. The main issues showed that the existing legal and institutional aspects are poorly designed, weakly administered, and inappropriate [10].

There was a growing need to address the established fact about a compounded issue of interrelationship which if well and properly orchestrated stands the chance of almost selfinstitutionalising a synergistic platform, the positive multiplier effect of which is going to be so tremendous on the performance, efficiency and effectiveness of formal land administration and regulation system, as well buoying the system for a 21st century relevance in addressing some of the most challenging requirements associated with lands delivery and accessibility of this age. This is best done by synchronising the trio of institutional economics, organisational arrangement and constitutional perspectives into evolving a very enduring conceptual framework that works as a veritable platform that is meant to continuously enhance, strengthen and establish the performances of land administration, hence Toulmin [28] puts forward the conceptual framework of institutions to cater for this ugly trend, especially for land registration and administration functions, all of which good interrelationship among various interrelated but dispersed units and divisions of land administration and regulation agencies have the potential to evolve, leverage and benefit from, so as to catalyse the process of formal delivery and accessibility of urban lands.

Therefore, a curious mind will like to among other things, pose some of these questions, which are begging for answers, thus: Why are land administration and regulation's units and divisions at a crossroad among one another? To what extent has this interrelationship challenge actually caused setbacks to optimal performance of formal land administration and regulation system? What are those factors that are responsible for non-robust output of formal land administration system? How best can relationship building mechanism be incorporated into the fabrics of formal land administration and regulation system? Can urban land acquisition challenges be totally solved or at least be drastically reduced, as well as clogs on the pathways of formal land delivery and accessibility be removed through some LASs-relationship buoying frameworks?

Therefore, it must be noted, that attempt to provide some explanations for the above queries, towards ensuring that interrelationship challenges among units and divisions of formal land administration and regulation systems for enhanced formal land delivery and accessibility and all-round better performance, that firstly, a thirdtier study which comes after the first and secondtier study on interrelationship issues among all formal lands' regulo-administartive machineries, such as this, to properly contextualise and assess, then later articulate the damning consequences that such trend portends for meaningful formal delivery and accessibility in the short run and ultimately leading to a sharp drop in the expansion of real estate and other physical assets as well as possibly losing land and housing rights in the long run; that is exactly the fulcrum around which this study was conducted.

\section{Methods and procedures}

Out of the total 586 individuals considered as the total population for the sample space, 120 individual qualified for the sample frame, upon which the structured questionnaires were distributed, with each of the questionnaires consisting of 20 mentally-stimulating items of queries, subsumed under 10 measuring constructs of parameters for apt and better understanding by the targeted respondents, 93 were successfully retrieved, from which 87 were considered valid, after integrity checks; from which primary data were collected from the all stakeholders within government's MDAs that are considered internal actors of the formal land regulo-administrative machineries as well as independent land consultants, various categories of land users and developers together with some NGOs whose mandates centre of shelter and are considered as external actors to the formal land regulo-administrative machineries, using simple convenience mixed with purposive sampling, so as to achieve a fair, balanced and unbiased research outcome from these two-opposing sets of respondents. Data that were gathered from field survey, were analysed with the aid of statistical methods of frequency and simple percentages in tabular forms via 5-point Likert measurement scale, from where logical inferences were drawn for the final interpretation of the research findings. 


\section{Data analyses}

The table 1 below sheds light on some of the responses of the stakeholders, as distilled from the returned questionnaires for analyses, with the application of average of the responses from the two determinant statements of each of the measuring parameters, to draw necessary inferences and judgement from the data displayed on the tables, thus:

Table 1 - Analyses of the Field Data, \%

\begin{tabular}{|c|c|c|c|c|c|}
\hline \multirow{2}{*}{$\mathrm{S} / \mathrm{N}$} & \multicolumn{5}{|c|}{$\begin{array}{c}\text { Constructs / Responses From LASs officials, Independent Land Consultants and Various Categories of Land } \\
\text { Users/ Developers. }\end{array}$} \\
\hline & SD & $\mathrm{D}$ & $\mathrm{U}$ & A & SA \\
\hline \multirow[t]{2}{*}{1.} & \multicolumn{5}{|c|}{ Myopism: P1RMS } \\
\hline & 6.9 & 10.91 & 2.88 & 52.30 & 27.01 \\
\hline \multirow[t]{2}{*}{2} & \multicolumn{5}{|c|}{ Non-Ingenuity: P2RMS } \\
\hline & 6.3 & 9.77 & 2.30 & 52.30 & 29.31 \\
\hline \multirow[t]{2}{*}{3} & \multicolumn{5}{|c|}{ Disservice: P3RMS } \\
\hline & 8.6 & 8.62 & 2.30 & 51.15 & 29.30 \\
\hline \multirow[t]{2}{*}{4} & \multicolumn{5}{|c|}{ Eco-Financial Loss: P4RMS } \\
\hline & 8.6 & 9.77 & 2.88 & 48.28 & 30.45 \\
\hline \multirow[t]{2}{*}{5.} & \multicolumn{5}{|c|}{ Distrust: P5RMS } \\
\hline & 8.0 & 8.62 & 4.03 & 48.85 & 30.44 \\
\hline \multirow[t]{2}{*}{6} & \multicolumn{5}{|c|}{ Trauma: P6RMS } \\
\hline & 8.9 & 9.52 & 2.75 & 46.39 & 31.93 \\
\hline \multirow[t]{2}{*}{7} & \multicolumn{5}{|c|}{ Anti-Growth: P7RMS } \\
\hline & 8.6 & 8.62 & 1.72 & 46.74 & 31.61 \\
\hline 8 & \multicolumn{5}{|c|}{ Death: P8RMS } \\
\hline & 8.6 & 8.62 & 2.30 & 51.15 & 29.30 \\
\hline 9 & \multicolumn{5}{|c|}{ Market Distortion: P9RMS } \\
\hline & 8.6 & 9.77 & 2.88 & 48.28 & 30.45 \\
\hline 10 & \multicolumn{5}{|c|}{ Thriving Informalisation: P10RMS } \\
\hline & 8.0 & 8.62 & 4.03 & 48.85 & 30.44 \\
\hline
\end{tabular}

Source: Authors' Field Survey, 2016

\section{Interpretation of results}

Table 1 above clearly shows the following as interpretations of all the 10 parameters, against which the impacts of interrelationship of Nigeria's lands regulo-administrative machineries were being measured, as distilled from the responses gathered from various categories of respondents from the field, thus:

1. Responses to the first parameter (Myopism) clearly show that Nigeria's formal lands reguloadministrative machineries presently battles with myopism brought by interrelationship crises and this adversely affects optimally delivery of formal land, with average of 46 respondents (52.30\%) agreeing and average of 24 respondents $(27.01 \%)$ strongly agreeing to the two determinant statements of this measurement parameter.
2. Responses to the second parameter (Noningenuity) denote glaringly that Nigeria's formal lands regulo-administrative machineries is presently faced with challenge of non-ingenuity as result of interrelationship problems and hence impinges on their efficiency seriously, which heightens the increased challenges of formal delivery and accessibility of urban land, with average of 46 respondents (52.30\%) agreeing and average of 26 respondents (29.31\%) strongly agreeing to the two determinant statements of this measurement parameter.

3. Responses to the third parameter (Disservice) explicitly establish that Nigeria's formal lands regulo-administrative machineries presently operate in a manner that exhibits all sorts of traces anti-civil service integrity and thus make them non-pragmatic to provide enduring solution to the teething challenges of formal lands acquisition, with average of 45 respondents (51.15\%) 
agreeing and average of 26 respondents $(29.30 \%)$ strongly agreeing to the two determinant statements of this measurement parameter.

4. Responses to the fourth parameter (EcoFinancial Loss) show that as a result of interrelationship pack-up among Nigeria's formal lands regulo-administrative machineries, losses of various kinds but with greater magnitude in terms of economic and financial losses as being suffered by prospective land users, are recorded on daily basis due to non-optimal delivery of formal land, with average of 42 respondents (48.28\%) agreeing and average of 27 respondents (30.45 \%) strongly agreeing to the two determinant statements of this measurement parameter.

5. Responses to the fifth parameter (Distrust) show that Nigeria's formal lands reguloadministrative machineries battles the challenge of mutual trust as result of non-beneficial interrelationship among them and this seriously stagnates their anticipated efficiency that would have guaranteed increased formal accessibility of urban land, with average of 43 respondents (48.85\%) agreeing and average of 28 respondents (30.44\%) strongly agreeing to the two determinant statements of this measurement parameter.

6. Responses to the sixth parameter (Trauma) copiously show that Nigeria's formal lands regulo-administrative machineries presently faces the challenge of interrelationship pack-up and has tremendously made delivering and accessing urban lands through the formal route very traumatic, especially for the prospective land users, with average of 42 respondents (46.39\%) agreeing and average of 28 respondents (31.93 \%) strongly agreeing to the two determinant statements of this measurement parameter.

7. Responses to the seventh parameter (AntiGrowth) show that the interrelationship issues among formal lands regulo-administrative machineries permeate into the greater picture of progress and development of the trio of the actors involved, the attendant effects of which deal greater blows on formal delivery and accessibility pathways, hence acting as clogs, with average of 43 respondents (46.74\%) agreeing and average of 28 respondents (31.61\%) strongly agreeing to the two determinant statements of this measurement parameter.
8. Responses to the eighth parameter (Death) show that Nigeria's formal lands reguloadministrative interrelationship imbroglio had heightened challenges associated with formal delivery and accessibility, which had manifested in all sorts of ugly experiences, including death arising from monumental eco-financial and other categories of losses with average of 45 respondents (51.15\%) agreeing and average of 26 respondents $(29.30 \%)$ strongly agreeing to the two determinant statements of this measurement parameter.

9. Responses to the ninth parameter (Market Distortions) obviously show that the interrelationship challenges inadvertently cause series of spiral trends in the dynamics of formal land market, which are tempting for land users it desperately consider for addressing their land-based needs, with average of 42 respondents (48.28 \%) agreeing and average of 27 respondents (30.45\%) strongly agreeing to the two determinant statements of this measurement parameter.

10. Responses to the tenth parameter (Thriving Informalisation) show that Nigeria's formal lands regulo-administrative crises bordering on interrelationship issues continues to brew fear of the unknown in the minds of all actors, especially the prospective land users, such that this trend had shifted the prism of consideration for the informal land accessibility, but at the expense of formal land accessibility, with unimaginablydaunting challenges thereto at the peril of theses unsuspecting land users, with average of 43 respondents (48.85\%) agreeing and average of 27 respondents $(30.44 \%)$ strongly agreeing to the two determinant statements of this measurement parameter.

\section{Summary and Discussion of Findings}

1. It was evident that the present level of myopic tendencies as empirically gathered is highly unacceptable within the context of the globallyattuned land administration system, which is expected to deliver the quantum of urban lands in Nigeria. Hence it stands to reason that unless urgent steps are taken to address this unfortunate trend in the breakdown of mutual interrelationship, informal land market which has begun to emerge might garner greater strength over and above the formal delivery mode, the consequences of such situation is better imagined than experience. 
2. Analysis of a parameter such as non-ingenuity was able to reveal how this interrelationship pack-up has succeeded in rendering our formal lands regulo-administrative machineries poorly, in terms of being far from having much desirable level of cutting-edge ingenuity to optimally deliver urban land formally, as sheer creativity is on its lowest ebb as a result of this trend., the implication this is enormous, the result of which have manifested as delays, considering the population of land applicants they are to serve, among other headaches.

3. Analysis on parameters such as disservice is highly worrisome, in that it tends to corroborate the seemingly perpetual stagnation among all the supply actors found in the formal land reguloadministrative machineries, their career advancement are skills-driven and the interrelationship crises had consistently made each stooping for relevance and at the end, none or few are reluctantly considered for advance skills acquisition and further training, the end products of all this, are borne by the continually dwarfed land delivery and accessibility which would have tremendously benefited, had it been the situation is otherwise.

4. The results on parameters such as ecofinancial loss reveal that the present ugly trend of losing virtually everything has invested into formally securing, due to interrelationship tussles among formal land regulo-administrative machineries, is better be quickly addressed before it gets of hands, as this as it were at moment has resulted all sorts of barbaric situation $\mathrm{n}$ the lives of these prospective land users.

5. The responses from majority of stakeholders point to the fact that the interrelationship crises among these formal lands regulo-administrative machineries had built a fabric of distrust among them, so much that whatever idea or creativity that might emerge from other units or divisions considered to be rival, can never have any acceptance however lofty such idea is, which if accepted could have positively contributed towards making formal lands delivery and accessibility a better ado.

6. The field results conveniently posits that the interrelationship blow-out from Nigeria's formal land regulo-administrative machineries subjects numerous prospective land users to traumatic experience of unimaginable dimension, due to consistent ills that bedevil the delivery and ac- cessibility of urban land via this route, the end of which is not predictable at moment. Hence, this ultimately leads to prolonged health challenge sometimes, which evidences have shown do cause untimely death in few cases.

7. The analyses on parameters such as market distortion and thriving informalisation points to the sorry state of our formal lands reguloadministrative machineries, whose interrelationship crises had sprung up quite funny and strange spiral of market imbalances as well as avoidable urban land imperfections, the attendant consequential effects of which had continually posed prospective land users in a sort state of dilemma, which calls for efforts on their part to seek solution to their enormous land-driven development requirements through informal route of accessibility of urban lands, with which daunting challenges are bound.

\section{Conclusion}

For the sake of emphasis, one must be fair to this formal land system by saying, the system is expediting all necessary efforts to make it at least one of the very best in African and perhaps, meeting up with the attainment of all the qualities expected of a world class system as years roll by. However, it is noteworthy that the present sorry state of affairs had really impacted so negatively on the entire formal land delivery and accessibility spectrum, firstly at the expense of the major actors on the supply side of the land accessibility debate, but most pathetic at the receiving end of it, are the prospective end users who are the actors at demand side of the debate. Therefore, it is suggestive to note that the inclusion of veterans as committee members on regulatory arm of the land administration and regulation system have been impactful in building a lasting platform of resolving all present areas of discordance, as well as ensuring a mechanism is evolved that frontally signals potential areas of crises-ignition in the structure and arrangement of functions among these units and divisions, so as perpetually address this quagmire, with a view to improving the formal delivery and accessibility of urban lands in Nigeria.

\section{Recommendation}

1. There is an urgent need for government to completely or at least partially restructure Nige- 
ria's formal lands regulo-administrative system, to remove possible areas that can be fingered by the trouble lookers among the officials of these formal land agencies for possible crises.

2. A mechanism that accentuates equity, justice, equality and fair-play must be evolved to address any pockets of role usurpation that can brew avoidable discordance that will later burgeon into interrelationship crises.

3. Overall reconfiguration of tasks and schedules as well as logically attaching them to appropriate units and divisions is germane.
4. Efforts should be quickly expedited to evolve a platform for synergy-building and strong collaboration among different units, divisions and actors involved, towards stemming the possibility of interrelation blow-out among them.

5 . The undercurrent of some of the salient reasons behind this ugly phenomenon is shrouded in economy. Government should endeavour to make the remuneration package of the officials of land agencies reasonable, so as to curb the tendencies that surround issues of role snatching and usurpation of different shades that do lead to interrelationship situations.

\section{References}

1. Abdul Karim, N. S., Maidin, A. J., Nordin, Z. A., \& Ismail, M. S. (2010). Electronic land administration system in Malaysia: a proposed review from ICT and legal perspectives. doi: 10.1109/ITSIM.2010.5561355

2. Abdullah, A. A., Harun, Z., \& Abdul Rahman, H. (2011). Planning process of development project in the Malaysian context: a crucial brief overview. International Journal of Applied Science and Technology, 1(2), 74-81. from http://www.ijastnet.com/journals/Vol._1_No._2;_April_2011/9.pdf

3. Angerbrandt, H. (2011). Political decentralisation and conflict: the Sharia crisis in Kaduna, Nigeria. Journal of Contemporary African Studies, 29(1), 15-31. doi: 10.1080/02589001.2011.533057

4. Arko-Adjei, A., Jong, J. De, Zevenbergen, J., \& Tuladhar, A. (2010, April 11-16). Customary tenure institutions and good governance. Retrieved from https://www.fig.net/resources/proceedings/fig_proceedings/fig2010/papers/inv04/inv04_ark oadjei_tuladhar_et_al_4279.pdf

5. Atilola, O. (2010, April 11-16). Land administration reform Nigerian: issues and prospects. Retrieved from

https://www.fig.net/resources/proceedings/fig_proceedings/fig2010/papers/inv04/inv04_atil ola_4758.pdf

6. Auzins, A. (2004). Institutional arrangements: a gate towards sustainable land use. Nordic Journal of Surveying and Real Estate Research, 1, 57-71. Retrieved from http://ojs.tsv.fi/index.php/njs/article/view/41506/10635

7. Awortwi, N. (2011). An unbreakable path? A comparative study of decentralization and local government development trajectories in Ghana and Uganda. International Review of Administrative Sciences, 77(2), 347-377. doi: 10.1177/0020852311399844

8. Bandeira, P., Sumpsi, J. M., \& Falconi, C. (2010). Land use policy evaluating land administration systems: a comparative method with an application to Peru and Honduras. Land Use Policy, 27, 351-363. doi: 10.1016/j.landusepol.2009.04.005

9. Bangsal, N., \& Lebrilla, M. L. (2008). Land administration system: functional and efficiency implications. $\quad$ Retrieved from http://www.academia.edu/1042675/Land_Administration_System_Functional_and_Efficiency_I mplications

10. Bennett, R., Wallace, J., \& Williamson, I. (2008). Organising land information for sustainable land administration. Land Use Policy, 25(1), 126-138. doi: 10.1016/j.landusepol.2007.03.006

11. Chimhamhiwa, D. (2010). Improving end to end delivery of land administration business processes through performance measurement and comparison (Doctoral thesis). Retrieved from https://researchspace.ukzn.ac.za/handle/10413/691

12. World Bank. (2010). Land Governance Assessment Framework Manual. World Bank Study on Governance in land administration. 
13. Enemark, S. (2008). Land management in support of the millennium development goals. Property Management, 26(4). doi: 10.1108/pm.2008.11326daa.001

14. Fitzpatrick, D. (2008). Managing conflict and sustaining recovery: land administration reform in Tsunami - affected Aceh. Singapore: Asia Research Institute \& Oxfam Internationa.

15. Grover, R. (2009, March 9-10). Measures to enhance trust in land administration systems and $\begin{array}{lllll}\text { engender their } & \text { use. } & \text { Retrieved }\end{array}$ https://www.fig.net/resources/proceedings/2009/fig_wb_2009/papers/mkt/mkt_2_grover.pdf

16. Hallebro, J. (2006, October 8-13). Stakeholder co-operation in Swedish Land Administration and Land Information. Retrieved from https://www.fig.net/resources/proceedings/fig_proceedings/fig2006/papers/ts89/ts89_01_hal lebro_0294.pdf

17. Herath, G. (2005). Analysis of potential and problems of new institutional economics for third world development. International Journal of Social Economics, 32(10), 877-892. doi: 10.1108/03068290510618515

18. Mansberger, R., Navratil, G., Muggenhuber, G., \& Twaroch, C. (2012). Is good governance in land administration measurable and comparable? Journal of Land Management, Food and Environment, 63(1), 27-34. Retrieved from https://diebodenkultur.boku.ac.at/volltexte/band63/heft-1/mansberger.pdf

19. Mason, J., \& Dale, A. (2011). Creative tensions in social research: questions of method. In J. Mason, and A. Dale, Understanding social research - thinking creatively about method (pp. 1-26). London: SAGE Publications Ltd.

20. Molen, P., \& Enemark, S. (2008). Capacity assessment in land administration. Denmark: International Federation of Surveyors.

21. Oladapo, R. A., \& Olotuah, A. O. (2007). Appropriate real estate laws and policies for sustainable development in Nigeria. Structural Survey, 25(3/4), 330-338. doi: 10.1108/02630800710772890

22. Olowu, D. (2003). Challenge of multi-level governance in developing countries and possible GIS applications. Habitat International, 27, 501-522. doi: 10.1016/S0197-3975(03)00003-1

23. Prasad, B. (2003). Institutional economics and economic development: the theory of property rights, economic development, good governance and the environment. International Journal of Social Economics, 30(6), 741-762. doi: 10.1108/03068290310474120

24. Rees, C. J., \& Hossain, F. (2010). Perspectives on decentralization and local governance in developing and transitional countries. International Journal of Public Administration, 33(12-13), 581-587. doi: 10.1080/01900692.2010.514459

25. Samsudin, S., Lim, L. C., \& McCluskey, W. (2011, May 18-22). A review of organizational arrangements in Malaysia land administration system towards good governance: issues and challenges.

Retrieved

from https://www.fig.net/resources/proceedings/fig_proceedings/fig2011/papers/ts07b/ts07b_salf arina_laycheng_et_al_4853.pdf

26. Samsudin, S., Lim, L. C., \& McCluskey, W. (2012, June 9-11). An analytical framework for assessing decentralized land administration governance performance. Retrieved from http://www.academia.edu/7964787/An_analytical_framework_for_assessing_decentralised_lan d_administration_governance_performance

27. Samsudin, S., Lim, L. C., \& McCluskey, W. (2013). Developing decentralised land administration governance assessment framework. In Management of Land and Sea Resources - What's New? Glasgow: Commonwealth Association of Surveying and Land Economy (CASLE).

28. Toulmin, C. (2008). Land use policy securing land and property rights in sub-Saharan Africa: the role of local institutions. Land Use Policy, 26, 10-19. doi: 10.1016/j.landusepol.2008.07.006

29. Ukaejiofo, A. N. (2009, April 11-16). Identifying appropriate tools for land governance in Nigeria. Retrieved from https://www.fig.net/resources/proceedings/fig_proceedings/fig2010/papers/ts05i/ts05i_ukaej iofo_4612.pdf

(C) K. B. Akinbola, M. Azlina Yassin 


\title{
Оценка последствий «автономной» структуризации системы управления земельными ресурсами городской системе передачи земли и доступности земельных ресурсов в Нигерии
}

\author{
Akinbola Kazeem Bolayemi \\ The Federal Polytechnic Ilaro, Department of Estate Management \&Valuation, Нигерия
}

\section{Md Yassin Azlina}

Universiti Tun Hussein Onn Malaysia, Department of Real Estate \& Facilities Management, Малайзия

\begin{abstract}
Аннотация. Известно, что производительность и эффективность системы управления земельными ресурсами зависит от очень многих факторов, возможно, главным из которых, является степень взаимности, согласованности и би-направленности взаимосвязи, которая существует между различными субъектами, обремененными собственными регуляторно-административными механизмами, которые ставят ряд задач. Несомненно, это простое ведение дел приводит к формальному распределению земельных участков и, следовательно, повышает доступность городских земель для нескольких категорий пользователей в Нигерии, так как этом случае делается во всем мире. Тем не менее, эти взаимосвязи отсутствуют в управлении земельными ресурсами и системе регулирования в Нигерии. Таким образом, данное исследование намерено оценить прямые и возможные косвенные последствия, которые эти взаимосвязи оказывают на формальную передачу и доступность городских земель в Нигерии.
\end{abstract}

Во-первых, это было сделано, формулируя вопросы, связанные с данной проблемой и калибруя их в концепции, а затем оценивая их с помощью следующих оценочных карт, а именно: миопизм, неизобретательность, ущерб, эко-финансовые потери, недоверие, травмы, антирост, смерть, искажение рынка и процветающая неформализация в Юго-Западной Нигерии. Из общего числа 586 лиц, рассматриваемых в качестве среднестатистического населения для выбранного для опроса района, 120 респондентам были предложены структурированные опросники для регуляторов земельных вопросов, земельных администраторов, независимых земельных консультантов и непосредственных пользователей земельных участков для того, чтобы сформировать честное и широкое представление о вопросах, связанных с дилеммой доступности земли. Было получено 93 анкеты, из которых 87 были признаны действительными, и, таким образом, легли в основу сделанного анализа, с акцентом на 5-бальной шкале Лайкерта с помощью умозаключений и описательных статистических инструментов. Результаты исследования показали, среди прочего, что трения в отношениях привели к необоснованному отбрасыванию ролей, что негативно влияет на темпы доставки, и одновременно приводит к перекосам на пути к формальному доступу к городским землям для различных категорий землепользователей. Среди рекомендаций следующие: государственные формальные земельные органы должны быть перенастроены для создания синергии, которая порождает положительную взаимосвязь и синхронизацию ролей в направлении улучшения формальной передачи земли и ее доступности в Нигерии.

Ключевые слова: воздействия; взаимосвязанность; регулировочно-административные механизмы; формальная доступность земельных участков; Нигерия.

удК 631.1

JEL Classification: Q15, Q24, R52

DOI: http://dx.doi.org/10.22178/pos.17-17

(C) K. B. Akinbola, M. Azlina Yassin

Статья получена 30.11.2016, принята 25.12.2016, опубликована оnline 28.12.2016 